\title{
A Preliminary Estimation of the Economic Costs of Lockdown in Rio Grande do Sul ${ }^{2}$
}

\section{Cristiano Aguiar de Oliveira ${ }^{1}$}

${ }^{1}$ Universidade Federal do Rio Grande (FURG), Rio Grande - RS, Brazil

This article seeks to estimate the initial economic costs of the measures adopted to mitigate the spread of COVID-19 in Rio Grande do Sul. To this goal, it uses a structural time series model estimated through Kalman Filter to obtain a counterfactual path of daily sales in the state after many municipals' decrees and the state decree number 55.128 of March 19, 2020. The results show that the accumulated costs of the lockdown policy in terms of losses on sales in the formal sector of the economy would be around BRL 43,34 billion and in terms of tax collection the losses would be around BRL 1,56 billion in only 27 days. Although the article has the limitation of using only information from the formal sector of the economy, it concludes that the costs of these measures are relevant and grow exponentially. It also concludes that it would be necessary for these measures to be able to prevent at least 13.158 deaths caused by COVID19 in the state of Rio Grande do Sul for their benefits to outweigh their costs.

Keywords: COVID-19, Lockdown, Kalman Filter, Rio Grande do Sul.

JEL Classification: C22, D61, K32

\section{Uma estimativa preliminar dos custos econômicos do lockdown no Rio Grande do Sul}

Este artigo busca estimar os custos econômicos iniciais das medidas adotadas para mitigar a propagação da COVID-19 no Rio Grande do Sul. Para este fim, utiliza um modelo estrutural de séries de tempo estimado através do Filtro de Kalman para obter uma trajetória contrafactual das vendas diárias no estado após vários decretos municipais e o decreto estadual n 55.128 de 19 de março de 2020. Os resultados mostram que os custos acumulados da política de isolamento social em termos de perdas com vendas no setor formal da economia seriam de cerca de $\mathrm{R} \$$

2 DOI: http://dx.doi.org/10.21874/rsp.v71i0.4830

Submitted: June 13, 2020 Published: June 17, 2020

ISSN: 0034-9240 | E-ISSN: 2357-8017

(). (1) (9)

REVISTA do SERVIço PúBlıco | Brasília 71(special) $22-41$ sept. 2020 
43,34 bilhões e em termos de perdas de arrecadação de ICMS seria algo em torno de R $\$ 1,56$ bilhão em 27 dias. Embora, o artigo possua a limitação de utilizar somente informações do setor formal da economia, este conclui que os custos dessas medidas são relevantes e que estes crescem exponencialmente. Conclui também que seria necessário que essas medidas fossem capazes de evitar pelo menos 13.158 mortes causadas por COVID-19 no estado do Rio Grande do Sul para que seus benefícios compensassem os seus custos.

Palavras-chave: COVID-19, isolamento social, Filtro de Kalman, Rio Grande do sul.

Classificação JEL: C22, D61, K32

\section{Una estimación preliminar de los costos económicos del lockdown en Rio Grande do Sul}

Este artículo busca estimar los costos económicos iniciales de las medidas adoptadas para mitigar la propagación del COVID-19 en Rio Grande do Sul. Para este fin, utiliza un modelo estructural de series de tiempo estimado a través del filtro de Kalman para obtener una ruta de ventas contrafactual en el estado después de varios decretos municipales y el decreto estadual n.55.128, del 19 de marzo de 2020. Los resultados muestran que los costos acumulados de la política de aislamiento social en términos de pérdidas en ventas em el sector formal rondarían los BRL 43.34 mil millones y en los términos de las pérdidas de cobro del ICMS serían de alrededor de BRL 1,56 mil millones en 27 días. Aunque el artículo tiene la limitación de usar solo información del sector formal de la economía, concluye que los costos de estas medidas son relevantes y que crecen exponencialmente. También concluyó que sería necesario que estas medidas pudieran prevenir al menos 13,158 muertes causadas por COVID-19 en el estado de Rio Grande do Sul para que sus beneficios superen sus costos.

Palabras-clave: COVID-19, Lockdown, Filtro de Kalman, Rio Grande do Sul.

Clasificación JEL: C22, D61, K32 


\section{Introduction}

Faced with an undeniable serious public health problem caused by the fast spread of SARS-COV-2, many policymakers had to quickly implement many measures to prevent overloading the health system to avoid, as much as possible, the deaths caused by lack of adequate medical care. This is because it is a new virus, easy to spread, which still does not have a vaccine and that generates a disease, COVID-19, that is still without a scientifically proven cure. For these reasons, it has been causing many deaths wherever it spreads.

The obvious recommendation in this case is to consider the knowledge of the health area, especially of infectious disease experts and epidemiologists. In these cases, what they indicate is the use of "non-pharmaceutical interventions", which consists of a series of measures ranging from hygiene recommendations, limitations to movement of people, closure of sites that potentially generate agglomerations to the isolation and quarantine of the infected people. It seems that there is also a consensus among researchers in the area based on the studies of Hatchett et al. (2007) and Markel et al. (2007) that the sooner measures aimed at reducing the agglomeration of people are implemented, the better their results in terms of reduction of peak contagion (flattening of the curve) and deaths ${ }^{15}$.

These ideas brought by researchers and health professionals certainly inspired several mayors and the governor of the state of Rio Grande do Sul to take some measures even before there were records of infected or widespread of the virus in the state. Thus, since March 18, 2020, about 1,600 municipal and state decrees related to the spread of the virus have been published in the state ${ }^{16}$. The most important are the state decrees No.55,128 of March 19, 2020 and No.55,154 of April 1, 2020, which instituted measures to limit the movement of people and established business closures (lockdown) throughout the state of Rio Grande do Sul. These measures are the ones that potentially have the greatest economic impacts and have the capacity to generate high costs for society. This is because these restrictive measures reduce or eliminate the ability of many people to work and/or to obtain income, which potentially affects their ability to support themselves economically in the present and in the future.

However, many of these measures are unprecedented and have been implemented without having a dimension, even approximate, to their costs and results, because the lockdown,

\footnotetext{
${ }^{15}$ Jackson et al. (2020) evaluate the impact of social isolation on different types of viruses from hospital records after a natural experiment caused by a heavy snowstorm in Seattle-WA that lasted two weeks. They show an opposite conclusion since they conclude that measures with short duration of social distancing can reduce the incidence of a virus if they are implemented close to the epidemic peak. Rashid et al. (2015) and Fong et al. (2020) also criticized these articles concluding that they present weak evidence in favor of these measures.

${ }^{16}$ These decrees can be accessed at https://leismunicipais.com.br/coronavirus.
} 
that is, the prohibition of virtually every type of activity involving public contact, is a new experience that has never been used in other pandemics and that has been tested only now by a large number of countries ${ }^{17}$, but still without robust assessments of its effectiveness ${ }^{18}$ at reducing the number of deaths by COVID-19 and its more general effects, in terms of well-being in the KaldorHicks sense, that is, through a cost-benefit analysis. In this context, a literature that deals precisely with trying to evaluate the economic impacts of the pandemic and to carry out cost-benefit assessments in all sectors of the economy is quickly appearing. This can already be seen, for example, in Acemoglu et al. (2020), Baldwin and Mauro (2020) and Ludvigson et al. (2020).

Nevertheless, in these studies, the impacts are estimated through simulation models of future scenarios, since economic information, unlike health statistics, usually takes a relatively long time to be publicized. This hinders the work of researchers, because there is virtually no daily economic information to allow the evaluation of the economic costs of lockdown measures while they are still in their implementation phase. Another difficulty in this evaluation process is the identification of control groups to create a counterfactual scenario to evaluate the real impact of these measures. In this type of policy, all sites are usually are treated or influenced by measures adopted elsewhere, because there is an economic connection among regions that generate externalities that are difficult to control.

Therefore, there are few methodological alternatives left. The simplest alternative, making a comparison of the same period of this year with the previous year, ignores many changes that occurred over this long period between one year and another, so information from the previous year is not a good predictor of current values. In this context, aiming to overcome these limitations, this study proposes to estimate the preliminary economic costs of the lockdown measures imposed by the decrees issued by the government of the state of Rio Grande do Sul and several municipalities from sales information obtained through the total value of electronic tax documents (DF-e) sourced by the state revenue department of Rio Grande do Sul. The empirical strategy used in this article consists in estimating a structural time series model with the use of Kalman's Filter (KF) from daily information over five months, from November 11, 2019 to April 15, 2020, to obtain an estimate of the counterfactual scenario (the total value in sales without the lockdown measures), which, when subtracted from the observed values, allows a more robust estimation

\footnotetext{
${ }^{17}$ For a brief description of these countries can be seen in https://www.businessinsider.com/countries-on-lockdowncoronavirus-italy-2020-3.

${ }^{18}$ Recent studies tried to evaluate these measures through models that allow inference about causality. But, not much is known so far, since Qiu et al. (2020) and Fang et al. (2020) use Chinese data that were significantly rectified after these studies had been conducted and Gupta et al. (2020) use American data that they also define as unreliable.
} 
of the costs of these measures to be obtained than through a simple comparison with the previous year or month ${ }^{19}$.

The choice of this methodology is justified by the lack of daily economic information and of comparable states not treated with similar measures to build a data panel that allows an analysis trough synthetic control or difference in differences models. Moreover, it is a more flexible and transparent methodology than the traditional Interrupted Time Series methodology, which is based on the traditional Box and Jenkins (1976) ARIMA models, such as the Gottman (1981) and Crosbie (1993) models. Structural time series models allow working with non-stationary series at their level, that is, with stochastic trend, something that is not possible in ARIMA models, and allow dealing with series with high variability, besides allowing the modeling of interventions, such as state decrees that are in force, through transparent statistical criteria (Harvey, 1989; Vuijic, Commandeur and Koopman, 2016).

Seeking to meet these objectives, the article is organized with three more sections besides this introduction. The next section describes in detail the empirical strategy. The third section describes the data and presents and discusses the obtained results. At the end of the article, some conclusions and future studies guidelines are presented for those who seek to carry out an evaluation of the efficiency of these measures.

\section{Empirical strategy}

This study uses the econometric model known as structural time series model. Following this model, the total values in sales is a univariate time series that can be represented in the following measurement equation:

$$
y_{t}=\mu_{t}+\psi_{t}+\gamma_{t}+\varepsilon_{t}
$$

where $\mu_{t}$ is the trend, $\psi_{t}$ is the cycle, $\gamma_{t}$ is the seasonal component and $\varepsilon_{t}$ is the error that reflects the shocks suffered by the series. According to Jalles (2009), an advantage of time series modeling with the use of structural models is its flexibility in identifying differences in the behavior of a series considering its different components as stochastic processes governed by random disturbances, so that each component has a transition equation, as follows:

\footnotetext{
${ }^{19}$ This method, which was popularized by Harvey (1989), Commandeur, and Koopman (2007) and Durbin and Koopman (2012), has been applied to assess the impacts of interventions in many areas of knowledge, including Harvey and Durbin (1986), which analyses the effects of the Law that mandated wearing seat belts in Britain on the deaths of drivers, and the study of Vujic, Commandeur and Koopman (2016), which analyzes the effects of the revocation of parole in the state of Virginia on crimes registered in the state.
} 
a) Trend $\left(\mu_{t}\right)$ : This component refers to the part capable of capturing smooth movements over long periods within the time series (Maia, 2003). A stochastic trend model can be written by:

$$
\begin{aligned}
& \mu_{t}=\mu_{t-1}+\beta_{t}+\eta_{t} \\
& \beta_{t}=\beta_{t-1}+\varpi_{t}
\end{aligned}
$$

which $\mu_{t}$ defines the level of the trend and $\beta_{t}$ defines its slope. In turn, $\eta_{t}$ it is a stochastic component of the level transition equation and $\varpi_{t}$ is the stochastic component of the slope transition equation.

b) Cycle $\left(\psi_{t}\right)$ : in many economic time series it is important to distinguish between a long-term trend and cyclical or short-term movements, which may have a deterministic or stochastic specification. A deterministic cycle perfectly describes a periodic behavior with a given frequency, so that it can be described as a function of sines and cosines in the following form:

$$
\psi_{t}=\alpha \cos (\lambda t)+\beta \operatorname{sen}(\lambda t)
$$

It is possible to add stochastic components in this equation, as well as including a damping factor within the equation, making the cycle more flexible and able to adapt to various functional forms. Doing this, we have:

$$
\left(\frac{\psi t}{\psi t *}\right)=\rho\left(\frac{\cos \lambda}{-\sin \lambda} \sin \lambda\right)\left(\frac{\psi t-1}{\psi * t-1}\right)+\left(\frac{\kappa t}{\kappa t *}\right)
$$

where $\rho$ is the parameter that determines the decay (damping) of the cycle, $\lambda$ is the parameter that determines the frequency of the cycle and $\kappa_{t}$ is the stochastic error component of the cycle transition equation.

c) Seasonality $\left(\gamma_{t}\right)$ : it is a movement that presents a repeated pattern over sub periods of a period considered. Following Koopman et al. (2007), the function for this component has the following form:

$$
\gamma_{t}=\sum_{j=1}^{s-1} \gamma_{t-j}+\delta_{t}
$$

where $\delta_{t}$ is the stochastic component of the seasonality transition equation. 
d) $\operatorname{Error}\left(\varepsilon_{t}\right)$ : the error, or also called innovations or the random movement of a time series is defined by Maia (2003) as a sporadic displacement of the time series, which is not captured by any of the other three components: trend, cycle and seasonality.

Therefore, following these specifications, any time series can be described in the statespace form, that is, through a measurement and transition equations for each component. Specifically in the model to be used in this study, in addition to the structural components, interventions will be added so that it is possible to capture possible structural breaks caused by the decrees in the levels of economic activity measured by the sales that use some type of electronic invoice. Thus, the time series of sales can be decomposed as follows:

$$
y_{t}=\mu_{t}+\psi_{t}+\gamma_{t}+\text { Interventions }+\varepsilon_{t}
$$

This model has a set of latent variables that can be estimated using the Kalman Filter. This filter is a recursive algorithm that can be described as a set of mathematical equations constituent of an efficient recursive estimation process that minimizes the squared errors ${ }^{20}$. To be applied, it is necessary that the models are written in the state-space form as described in the equation (6), or in its matrix form, given by:

$$
Y_{t}=Z_{t} X_{t}+d_{t}+\varepsilon_{t} \quad \text { with } \quad t=1,2, \ldots, \quad T
$$

in which $Z_{t}$ it is an $\mathrm{N} \times m$ matrix, $d_{t}$ is an $\mathrm{N} \times 1$ vector, $\varepsilon_{t}$ is a serially uncorrelated vector with zero mean and covariance matrix $H_{t}$, and $X_{t}$ is an $m \times 1$ vector that contains the unobservable state variables. If the state variables (structural components) can be represented through an Markovian process of order one, such as the transition equations described by equations (2), (3), (4) and (5), the matrix version that represents the set of transition equations is given by:

$$
X_{t}=T_{t} X_{t-1}+C_{t}+R_{t} N_{t} \quad \text { with } \quad t=1,2, \ldots, \quad T
$$

Where $T_{t}$ is an $m \times m$ matrix, $C_{t}$ is an $m \times 1$ vector, $R_{t}$ is an $m \times g$ matrix, and $N_{t}$ is a vector $g \times 1$ not serially correlated stochastic components with zero mean and covariance matrix given by $Q_{t}$. Written in this form, the unobserved components of the structural models of time series can be obtained recursively by the filter.

\footnotetext{
${ }^{20}$ Other point to be emphasized is that KF allows the estimation of unknown parameters of the model by maximizing likelihood via decomposition of prediction errors.
} 
In turn, structural breaks can be identified visually or from the knowledge of periods in which changes may have generated a significant change in the time series (Campbell and Ross, 1968). In this case, it is assumed that any change in another covariate moves more slowly and gradually than the variable that generated the intervention (structural break). For this structural break identification to have internal validity, i.e., for the model to be able to estimate causal effects, it is necessary that the change generates permanent effects so that the different behaviors of the series before and after the intervention are evident (Linden and Arbor, 2015). This is a crucial point of the empirical strategy used in this study, because obtaining the counterfactual scenario that allows an estimate of the costs of lockdown measures is only possible if there is a separation of the treatment effect that is performed through the identification of these structural breaks.

In this context, structural time series models are useful precisely to minimize these problems, as they allow the robust identification of structural breaks. So, unlike traditional methods that use deterministic trends to build the forecast that serves as a "placebo" series, structural time series models treat all components as stochastic and independent of model errors. Thus, we have a much more accurate forecast that allows us to obtain a robust counterfactual analysis based on the identification of the structural breaks presented by the series, that is, it allows us to generate a "placebo" series and to measure the treatment effects.

Considering these aspects, the strategy of identifying the costs of lockdown measures implemented in the state of Rio Grande do Sul through state decrees No.55,128 of March 19, 2020 and No.55,154 of April 1, 2020 and several other municipal decrees consists of two stages, suggested by Vujiceur, Commandeur and Koopman (2016).

The first stage establishes the use in the intervention model on the relevant dates related to historical events. The coincidence implies a strong indication of a causal relationship between the changes imposed by the decrees and the total sales. In this case, the internal validity is not complete unless there is the omission of any relevant variable that moves at the same speed of the intervention.

In this study, two interventions are evaluated. The first is the state decree No.55,128, of March 19, 2020, which among other measures establishes ${ }^{21}$, the prohibition of the movement of interstate public and private buses, the stores closure at shopping malls, the limitation of the service capacity of supermarkets, pharmacies, ATMs and restaurants, the prohibition of public gatherings and meetings of any nature, including excursions, face-to-face courses, religious events with more than 30 people, limitations to intercity transport within the stateof up to $50 \%$

\footnotetext{
${ }^{21}$ The complete decree can be accessed in https://www.diariooficial.rs.gov.br/materia?id=396798.
} 
capacity, and requires that buses for urban and rural public transport to operate only with seated passengers, among other measures with less economic impact. The second intervention is state decree No.55,154 of April 1, which determined the business closure ${ }^{22}$ throughout the state of Rio Grande do Sul except for activities considered essential described in Article 17 of the same decree.

The second stage consists of estimating a "placebo" trajectory of the sales series based on its components excluding shocks (irregular component or innovation), since these cannot be predicted before they occur and, the measured effects of the interventions. This makes possible to obtain an estimate of the costs, in terms of total daily sales, of lockdown measures when comparing their observed (real) trajectory with their counterfactual estimate (placebo).

\section{Results}

The data for the execution of this study were extracted from the database of the state revenue department of Rio Grande do Sul. For the estimation of the model, the daily statistics of the total amounts of tax documents issued in Rio Grande do Sul (output) in the period between November 11, 2019 and April 15, 2020 were used. The study ends on the date of publication of a new decree, state decree $n^{\circ} 55.184$ of April 15, 2020, which transferred the responsibility to decide about the business opening to city halls, with the exception of those located in the metropolitan area of Porto Alegre, state capital and region of the state with the highest number of registered cases and deaths by COVID-19. Electronic tax documents (DF-e) comprise the sum of electronic invoices (NF-e), which are issued as in all commercial transactions involving the movement of goods, such as sale to legal entities, return, transfer, among others; Electronic Invoice of Consumers (NFC-e), which are issued in face-to-face sales or home delivery to the final consumer; Electronic Transportation Knowledge (CT-e), issued to cover operations of delivery of cargo transportation service; Electronic Ticket (BP-e) issued to register the services of passenger transportation, such as road transport, waterway, rail, among others.

Graph 1 shows the trajectory of the used series. As can be observed the total value is composed in its almost totality by NF-e. Moreover, it is possible to observe that the series has a well-defined daily seasonal pattern, with abrupt reduction at weekends, which makes it difficult to identify any trend or structural break in the series through simple visualization.

\footnotetext{
${ }^{22}$ The complete decree can be accessed in https://saude-admin.rs.gov.br/upload/arquivos/202004/01140149-decreto55154.pdf.
} 
Graph 1. Total value issued per day in NF-e and DF-e (Total) in Rio Grande do Sul (BRL billions)

12

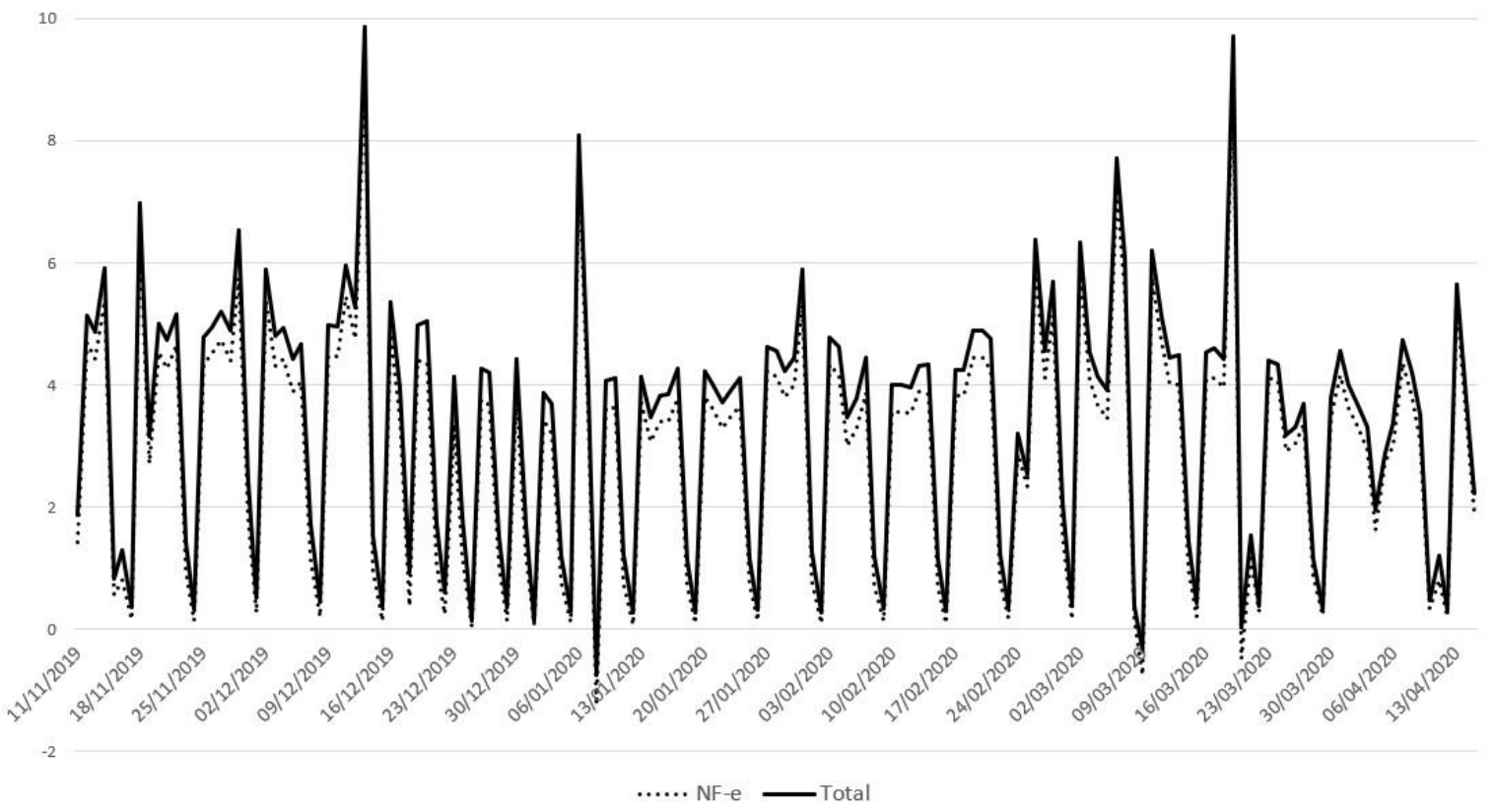

Source: State revenue department of Rio Grande do Sul.

As already mentioned, the identification strategy involves including interventions in the structural models. Once the dates of possible discrepant information and/or structural breaks are established, structural time series models are estimated with three types of possible specifications for the dates: outlier, slope break and level break.

Starting from the most complete to the simplest model, models with specifications with statistically significant coefficients are chosen. The results of this process of searching for the best adjustment to the data generating process can be seen in Table 1. The model with the best adjustment does not present a residuals autocorrelation problem ${ }^{23}$ as can be seen in the LjungBox test, however, the Jarque-Bera test indicates that the model does not have normality in the distribution of its residuals ${ }^{24}$.

\footnotetext{
${ }^{23}$ Table A.1. appendix shows the residual's distribution and correlogram.

${ }^{24}$ It is noteworthy that even if the hypothesis of normality of the residuals is not satisfied, yet the so the estimator obtained by the Kalman Filter is an optimal linear estimator that minimizes the mean quadratic error (Harvey, 1989).
} 
Table 1. Results of estimates for the sales in Rio Grande do Sul.

\begin{tabular}{|c|c|c|c|c|c|}
\hline $\begin{array}{l}\boldsymbol{T} \\
157\end{array}$ & $\begin{array}{l}\boldsymbol{p} \\
2\end{array}$ & $\begin{array}{l}\text { Normality (JB) } \\
62.762 \\
(0.000)\end{array}$ & $\begin{array}{l}q \\
13\end{array}$ & $\begin{array}{l}\boldsymbol{Q}(\boldsymbol{q}, \boldsymbol{q}-\boldsymbol{p}) \\
21.021 \\
(0.0725)\end{array}$ & $\begin{array}{l}\boldsymbol{R}^{2} \boldsymbol{d} \\
0.7488\end{array}$ \\
\hline \multicolumn{6}{|c|}{ Regression effects in the last period (15/4) } \\
\hline & Coefficient & RMSE & t test & P-value & \\
\hline Slope break (20/3) & -1.8356 & 0.76594 & -2.397 & 0.0177 & \\
\hline Slope break (21/3) & 1.8542 & 0.78751 & 2.354 & 0.0198 & \\
\hline Monday & 4.00839 & 0.42017 & 9.539 & 0.0000 & \\
\hline Tuesday & 3.62839 & 0.42091 & 8.620 & 0.0000 & \\
\hline Wednesday & 3.15359 & 0.42146 & 7.482 & 0.0000 & \\
\hline Thursday & 4.04882 & 0.42597 & 9.504 & 0.0000 & \\
\hline Friday & 3.96883 & 0.43538 & 9.330 & 0.0000 & \\
\hline Saturday & 1.20312 & 0.42446 & 2.834 & 0.0005 & \\
\hline
\end{tabular}

Source: Own elaboration with the use of Stamp software

As can be seen in Table 1, statistically significant changes in slope breaks were identified in two periods ${ }^{25}$, one with a negative impact on total sales and the other with a positive impact. The first of these occurred shortly after the first wave of municipal decrees and state decree $\mathrm{n}^{\circ}$ 55.128 , on March 20, while the second breach has a positive impact and occurs on the following day, however, as can be seen in the Figure 1-c, the sum of the two breaks generates a negative net effect that starts at around BRL 1.8 billion per day and that is reduced in the subsequent periods, but remains negative in net terms until the final period in April 15th.

In addition, figure 1 graphically presents the other components of the series, which, as can be seen in figure 1-d, it shows a growing (stochastic) trend until April 1, date of state decree $\mathrm{n}^{\circ}$ 55.154 , which prohibited activities of commerce throughout the state of Rio Grande do Sul. From that date on, the trend shows a decrease in sales. In other words, this decree was not able to generate a structural break in the sales series, but it changed its trend, which became negative. The estimation also shows that the daily seasonal component of the series is quite statistically significant, and that Thursday and Friday are the days that usually present the highest sales volume in Rio Grande do Sul. These are, on average, about BRL 4.04 billion higher than what is usually registered on Sundays. It is also possible to observe that Saturday is also a day of the week with low sales volume.

${ }^{25}$ No statistically significant structural breaks were identified in subsequent periods, including after State Decree No. 55,154 of April 1. 
Figure 1. Structural components of the sales series in the state of Rio Grande do Sul
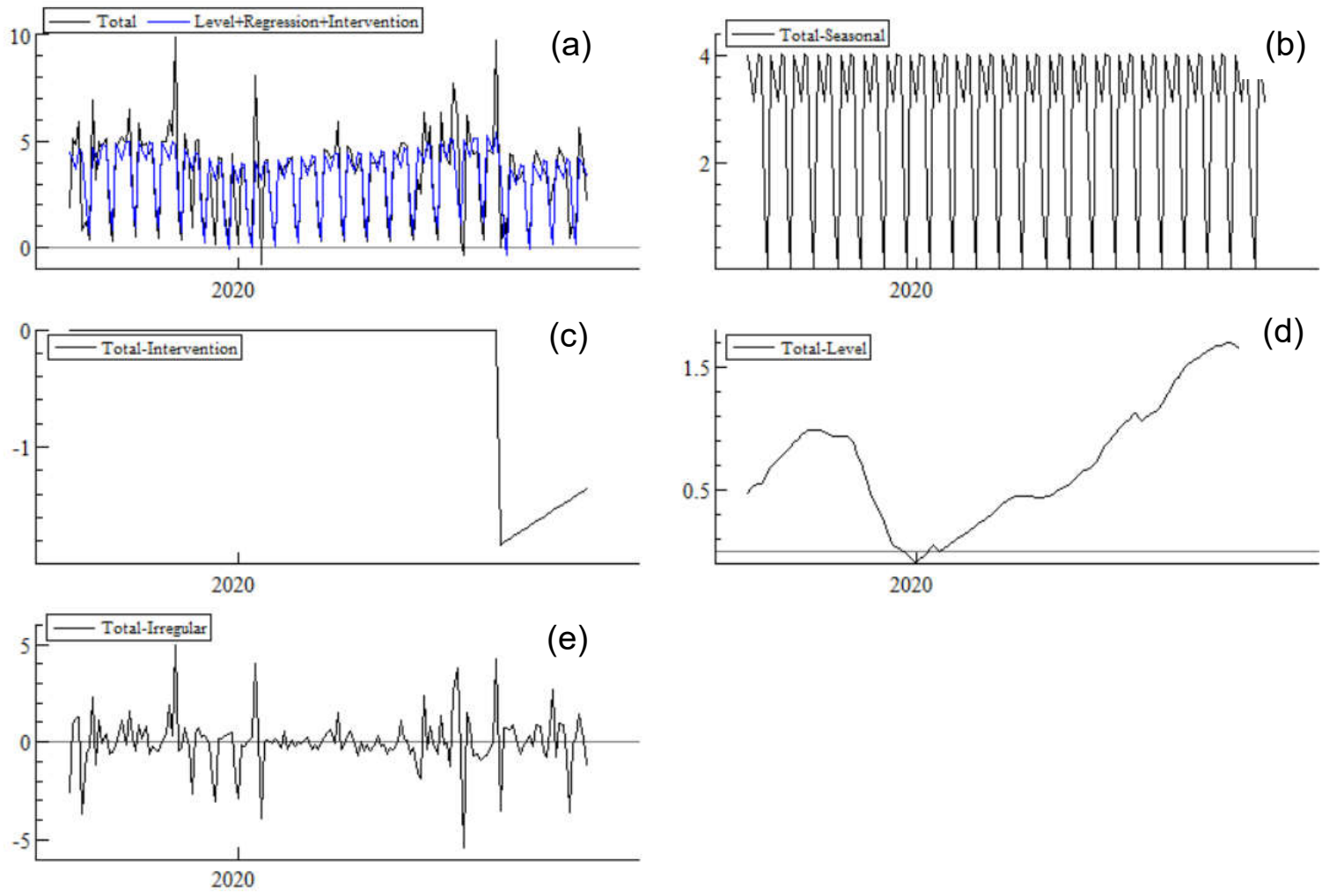

Source: Own elaboration with the use of Stamp software.

Note: Values in vertical axis are in BRL billions.

As described in the previous section, the identification strategy involves estimating a "placebo" series from the structural components of the total value in sales using some electronic invoice in Rio Grande do Sul. This is obtained by adding the components of the series excluding shocks, so called irregular in figure 1, and the intervention components, so called intervention in the same figure. This "placebo" series is represented by the gray line in Graph 2. It should be noted that this gray line is the adjusted series before interventions occur and that this becomes the "placebo" series only after these occur. After the first intervention, the adjusted model, represented by the red line, follows a different trajectory because of the lockdown measures (treatment). 
Graph 2. Total sales estimated and observed using electronic invoice in Rio Grande do Sul (March 1-April 15, 2020)

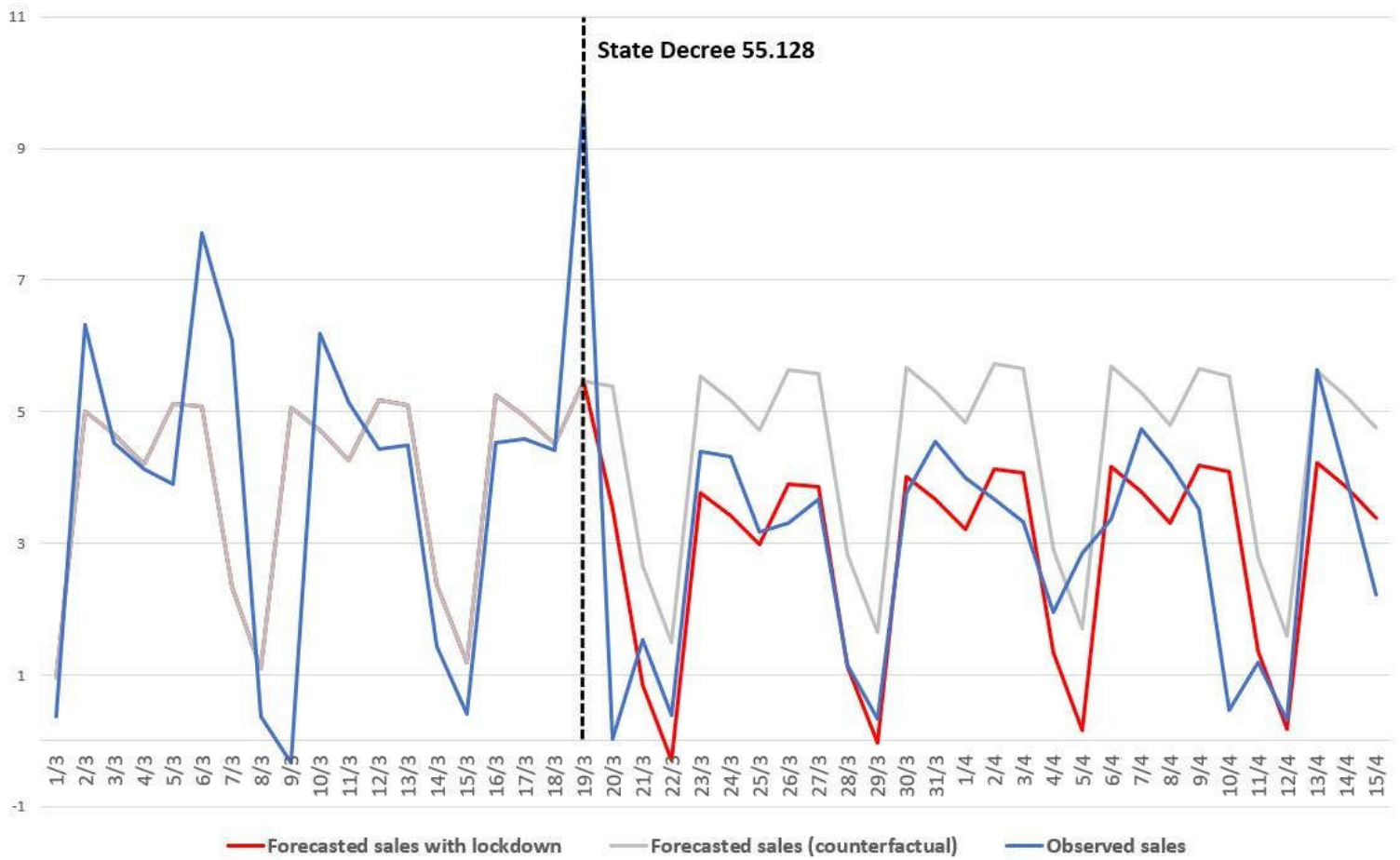

Source: Own elaboration with the use of Stamp software. Note: Values in vertical axis are in BRL billions.

In this way, the adjustment of the model can be assessed ${ }^{26}$ by comparing the observed values, represented by the blue line in the graph, with the estimated values (gray line) before the interventions and with the estimated values considering the impacts of the interventions (red line), after interventions occur. Considering these aspects, it is possible to observe that the model was not able to predict the sudden increase in sales that occurred on March 19, as soon as the announcements of the first decrees that limited the mobility of people in the state of Rio Grande do Sul occurred. There was an increase in sales of food and hygiene products on this day because many consumers faced the prospect of staying at home for a long time and there were rumors that there might be a shortage of basic products, such as toilet paper. These shortages ended up not being confirmed. However, the model shows a strong adjustment between 27 March and 5 April and 11 and 12 April.

Following the analysis of the results, it remains only to present the main conclusion of the article, which is an estimation of the total cost, measured in terms of sales losses, of the lockdown measures in Rio Grande do Sul. This is obtained by adding the difference between series

\footnotetext{
${ }^{26}$ This can also be done through the $\mathrm{R}^{2} \mathrm{~d}$ observed in table 1, equal to 0.7488 , and observing Figure 1 -a.
} 
counterfactual (gray line) and the observed series (blue line), from the first intervention on March 19 , identified in the graph by the first vertical dotted line. Using this empirical identification strategy, the estimated impact was a reduction in sales of approximately BRL 43.34 billion, which represents a reduction of approximately $43.18 \%$ of the expected sales for the period. This value allows, for example, to have an estimate of the loss of tax collection with the ICMS, since the revenues from this tax usually represent $3.6 \%$ of the total sales value with the use of electronic invoices. Thus, the collection losses with this tax, which is the most relevant tax collected by states in Brazil (VAT equivalent), would be around BRL 1.56 billion, that is, approximately $51 \%$ of the expected collection for this tax for the month of April. This loss of revenue is certainly relevant considering that the state has severe financial issues and usually pays its public employees' wages in parts.

Graph 3. Estimated accumulated losses on sales due to lockdown measures in Rio Grande do Sul (March 20-April 15, 2020)

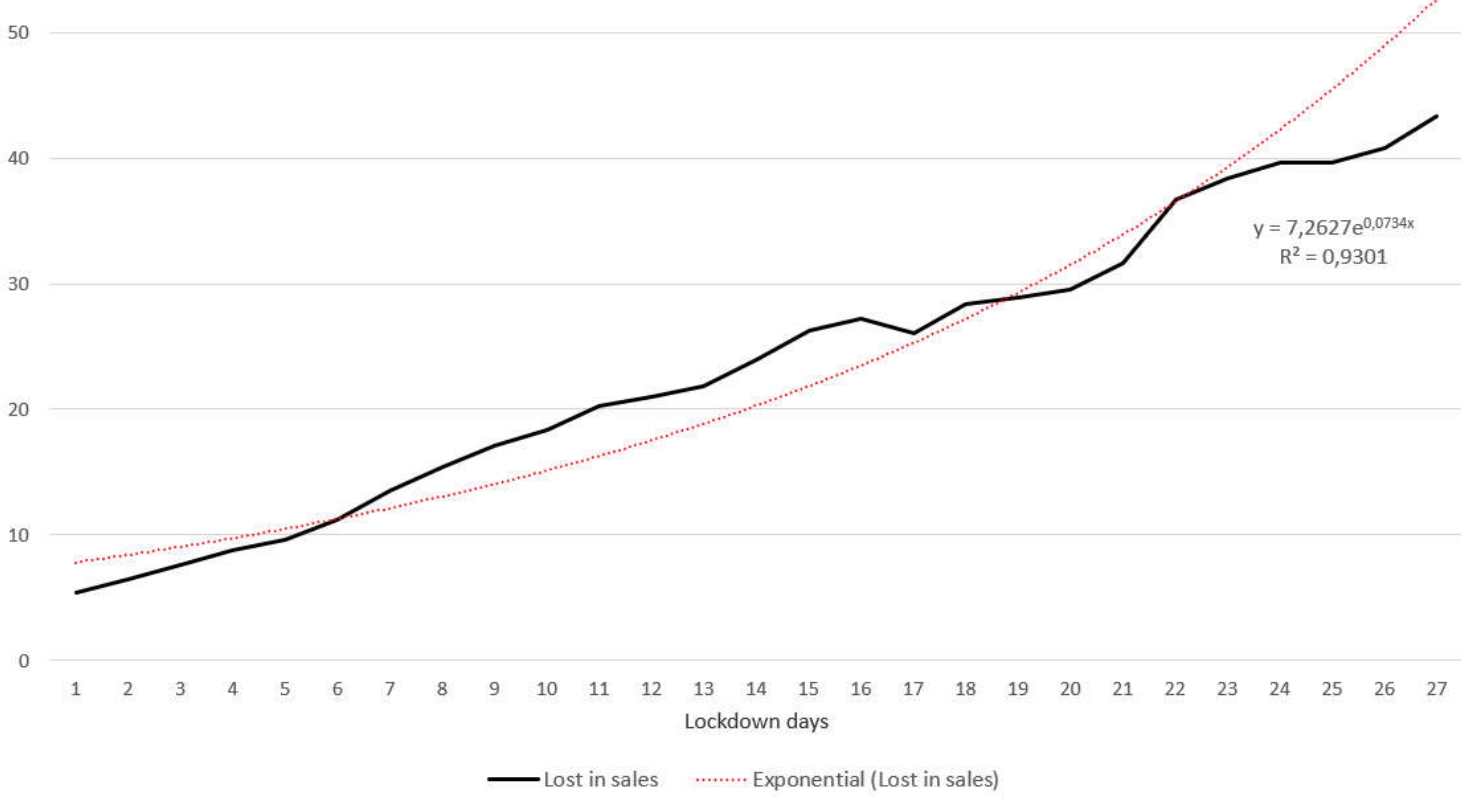

Source: Own elaboration. Note: Values in vertical axis are in BRL billions.

Since the losses have a daily periodicity and vary from day to day, it is possible to build a graph with the costs accumulated since the implementation of social isolation measures in the state of Rio Grande do Sul. This exercise is shown in graph 3.

The graph shows that the accumulated (sales) losses grow in a non-linear manner. These started growing at an exponential rate lower than estimated and shown on the graph until the sixth 
day of the lockdown. From that day on, growth was higher until the sixteenth day, which coincides with the fifth day of April, the day on which the counterfactual model predicted a drop greater than that observed possibly because it was the first Sunday of the month, a period in which people are getting their wages. However, this small interruption in the growth of losses was followed by a more accelerated growth in the following periods until the twenty-second day, April 11th. From this day onwards the estimated losses show a slowdown. Even so, these are not negligible, since, for example, on the last day evaluated, on April 15 the estimated loss was more than BRL 2.5 billion.

Therefore, it is possible to conclude that it is not only the spread of the virus that can generate exponential costs. The results obtained in this article indicate that the losses in the economy, as well as the potential number of infected and deaths caused by the virus, also grow exponentially.

\section{Conclusion}

The main objective of this article was to obtain estimates for the initial economic costs of lockdown measures imposed by municipal decrees and state decrees $n^{\circ} 55.128$ of March 19, 2020 and $n^{\circ} 55.154$ of April 1, 2020. To this end, we estimated a "placebo" series obtained through a structural time series model, which allowed us to conclude that the costs, measured in terms of sales losses realized in the state of Rio Grande do Sul, would be approximately BRL 43.34 billion in 27 days of effective social isolation measures.

It should be noted that these costs involve only losses in the formal sector of the economy that uses an electronic system for paying taxes. Therefore, the model does not allow estimating lossesin the informal sectors of the state's economy, which are possibly even more affected by the measures. Assessing the costs of these measures in terms of employment and income is a natural extension of this study, as well as carrying out an assessment of the impacts of these measures in the long term, which will only be possible to be done after the first after the pandemic outbreak has ended.

In any case, the cost estimation presented in this study, despite its limitations, is the first step to conduct a cost-benefit analysis of lockdown measures. However, for it to be done, it is necessary to evaluate the benefits of these measures, which also involves obtaining a counterfactual scenario, since, for example, the number of hospitalizations and deaths avoided are not observed. In this case, the task of obtaining a "placebo" series is much more complicated because when a new virus spreads, information from other outbreaks is not informative and does not contribute to building forecasting models. Therefore, unlike the economic variables in which 
the past usually helps to project the future, the past behavior of the variables of interest in the health sector does not contribute too much to setting up a counterfactual scenario.

It is worth remembering that the epidemiological literature shows that the only way to reduce deaths is with the treatment of the population with drugs or vaccines (Fong et al, 2020). Social isolation measures would be necessary only to postpone people's infection and what is expected is that the postponement is sufficient to prepare a minimum structure to give care for the infected and find a form of treatment capable of reducing deaths. However, this is not something simple to happen and it usually takes much longer than 15 or 30 days, which are the periods of validity foreseen for lockdown measures in most of the decrees established in Rio Grande do Sul.

Thus, the cost-benefit assessment of these measures must balance the number of lives saved by treatment in the future, since without effective treatment, there is only a postponement of deaths and the number of lives disorganized and lost by loss of their ability to earn a living ${ }^{27}$. In other words, there is no guaranteed gain for the lockdown, because, if treatment is not discovered in time, this gain does not exist, while in return its costs in the economy, as shown in this study, grow exponentially when economic activities are subject to many restrictions.

At this time, when there is no reliable estimate of the benefits of these measures ${ }^{28}$, the only possible analysis that resembles a cost-benefit assessment is to compare the costs estimated in this article with the estimated values for the value of life. Mesquita et al. (2020) estimate that the Value of Statistical Life (VSL) in Brazil is around BRL 3.294 million. These values are close to those found by Viscusi and Masterman (2017) in their meta-analysis on VSL performed for several countries in the world. Thus, this value can be used as a reference to do a reverse reasoning, that is, how many lives should be saved to offset the costs imposed by the lockdown measures.

The results obtained in this article indicate that in Rio Grande do Sul at least 13,158 people should be saved in this period or in the future so that their costs are offset by their benefits, measured in terms of lives saved. If only this period in which the measures are in force and that until April 15, 19 deaths by COVID-19 were recorded in the state, this implies that the lockdown

\footnotetext{
${ }^{27}$ It can be argued that it is at this point, then, that government aid should be offered to the groups that are most affected by lockdown measures through programs including cash transfer programs, company subsidies and postponement of tax payments. Programs of this type are already underway; however, it cannot be ignored that governments in all their spheres in Brazil have financial problems and that they will also have significant losses of revenue, so it is impossible to build a program equivalent to the level of the private sector losses. For example, the estimated costs in this study for about four weeks of lockdown in Rio Grande do Sul are equivalent to almost $62 \%$ of the expected revenues for the state government in 2020. In fact, only a small portion of the losses is possible to be replenished.

${ }^{28}$ Oliveira (2020) and Desmet and Wacziarg (2020) tries to estimate these benefits using Brazilian and American daily panel data, respectively. They both found that these measures are capable to reduce cases and deaths by COVID-19; however, caution is needed when interpreting these results because their models do not have a design that allows inferring about causality.
} 
measures should have an effectiveness of $99.8 \%$, or that is, they would be able to reduce deaths caused by the virus by this percentage. It is clear that this percentage changes as the costs of maintaining the lockdown increase and the number of deaths also increases.

Finally, it is necessary to reaffirm the need for lockdown measures to be carefully analyzed in a perspective of cost-benefit analysis. As already mentioned in this study, when imposing an economic lockdown, policy makers entered an unknown environment, as, to date, there are no studies that attest to its effectiveness or that evaluate its costs, so there is a strong possibility that significant losses (even if not intentional) are generated that are not expected by their proponents. There is not even a guarantee that this type of measure will actually be implemented in the desired way, since the population have incentives not to comply with them considering that it is a measure with extremely high monitoring costs by the State and with benefits of not complying with it as the lockdown continues and the need to seek support from the population increases.

\section{References}

ACEMOGLU, D.; CHERNOZHUKOV, V.; WERNING, I.; WHINSTON, M. D. Optimal Targeted Lockdowns in a Multi-Group SIR Model. Working Paper, National Bureau of Economic Research, 2020.

BALDWIN, R.; DI MAURO, B. Economics in the Time of COVID-19 . CEPR Press VoxEU.org eBook, 2020.

BOX, G. E.; JENKINS, G. M. Time series analysis: forecasting and control. Revised ed. [S.I.]: Holden-Day, 1976.

CAMPBELL, D. T.; ROSS, H. L. The Connecticut crackdown on speeding: time-series data in quasi-experimental analysis. Law and Society Review, v. 3, n. 1, p. 33-54, 1968.

CAMPBELL, D. T.; STANLEY, J. C. Experimental and quasi-experimental designs for research. [S.I.]: Ravenio Books, 2015.

COOK, T. D.; CAMPBELL, D. T. The design and conduct of quasi-experiments and true experiments in field settings. In: DUNNETTE, M. D. (ed.). Handbook of industrial and organizational psychology. Chicago: Rand McNally College, 1976. p. 223-326.

COMMANDEUR, J. J. F.; KOOPMAN, S. J. An introduction to state space time series analysis. Oxford: Oxford University Press, 2007. 
CORREIA, S.; LUCK, S.; VERNER, E. Pandemics Depress the Economy, Public Health Interventions Do Not: Evidence from the 1918 Flu. Rochester, NY: Social Science Research Network, 2020. Available from: <https://papers.ssrn.com/abstract=3561560>. Accessed: $7 / 4 / 2020$.

CROSBIE, J. Interrupted time-series analysis with brief single-subject data. Journal of Consulting and Clinical Psychology, v. 61, n. 6, p. 966, 1993.

DESMET, K.; WACZIARG, R. Understanding Spatial Variation in COVID-19 across the United States. Working Paper, National Bureau of Economic Research, 2020.

DURBIN, J.; KOOPMAN, S. J. Time series analysis by state space methods. 2nd ed. Oxford: Oxford University Press, 2012.

FANG, H.; WANG, L.; YANG, Y. Human Mobility Restrictions and the Spread of the Novel Coronavirus (2019-nCoV) in China. Working Paper, National Bureau of Economic Research, 2020.

FONG, M. W.; GAO, H.; WONG, J. Y.; et al. Nonpharmaceutical Measures for Pandemic Influenza in Nonhealthcare Settings-Social Distancing Measures - Volume 26, Number 5-May 2020 Emerging Infectious Diseases journal - CDC. Available from: <https://wwwnc.cdc.gov/eid/article/26/5/19-0995_article>. Accessed: 1/5/2020.

GOTTMAN, J. M. Time-series analysis: a comprehensive introduction for social scientists. Cambridge: Cambridge University Press, 1981. v. 400.

GUPTA, S.; NGUYEN, T. D.; ROJAS, F. L.; et al. Tracking Public and Private Responses to the COVID-19 Epidemic: Evidence from State and Local Government Actions. Working Paper, National Bureau of Economic Research, 2020.

HATCHETT, R. J.; MECHER, C.E.; LIPSITCH, M. Public health interventions and epidemic intensity during the 1918 influenza pandemic. Proceedings of the National Academy of Sciences, 104(18), p.7582-7587, 2007.

HARVEY, A. C. Forecasting, structural time series models and the Kalman filter. Cambridge: Cambridge University Press, 1989.

HARVEY, A. C.; DURBIN, J. The effects of seat belt legislation on British road casualties: a case study in structural time series modelling. Journal Royal Statistics Society Series A, v. 149, p. 187227, 1986.

JACKSON, M. L.; HART, G. R.; MCCULLOCH, D. J.; et al. Effects of weather-related social distancing on city-scale transmission of respiratory viruses. medRxiv, 2020. Cold Spring Harbor 
<https://www.medrxiv.org/content/early/2020/03/03/2020.03.02.20027599>. Accessed: 1/5/2020.

JALLES, J. T. Structural time series models and the Kalman filter: a concise review. Cambridge: University of Cambridge, 2009.

KOOPMAN, S. J.; HARVEY, A.; DOORNIK, J.; SHEPHARD, N. Stamp 8: structural time series analyzer, modeller and predictor. [S.I.]: Timberlake Consultants, 2007.

LINDEN, A.; ARBOR, A. Conducting interrupted time-series analysis for single-and multiple-group comparisons. Stata Journal, v. 15, n. 2, p. 480-500, 2015.

LUDVIGSON, S.C.; MA, S.; NG, S. Covid19 and the Macroeconomic Effects of Costly Disasters. NBER Working Paper Nº 26987, April 2020.

MARKEL, H.; LIPMAN, H. B.; NAVARRO, J. A.; SLOAN, A.; MICHALSEN, J.R.; A. M. STERN, A.M.; CETRON, M.S. Nonpharmaceutical Interventions Implemented by US Cities During the 1918-1919 Influenza Pandemic. JAMA, 298(6), p.644-654, 2007.

MESQUITA, R.; ALMEIDA A. N.; OLIVEIRA; C. O valor estatístico de uma vida: estimativas para o Brasil. Estudos Econômicos, forthcoming, 2020.

OLIVEIRA, C. Does "Staying at Home" Save Lives? An Estimation of the Impacts of Social Isolation in the Registered Cases and Deaths by COVID-19 in Brazil. SSRN Scholarly Paper, Rochester, NY: Social Science Research Network, 2020.

RASHID, H.; RIDDA, I.; KING, C.; et al. Evidence compendium and advice on social distancing and other related measures for response to an influenza pandemic. Pediatric Respiratory Reviews, v. 16, n. 2, p. 119-126, 2015.

SHADISH, W. R.; COOK, T. D.; CAMPBELL, D. T. Experimental and quasi-experimental designs for generalized causal inference. [S.I.]: Wadsworth Cengage Learning, 2002.

VISCUSI, W. K; MASTERMAN C. Anchoring Biases in International Estimates of the Value of a Statistical Life. Journal of Risk and Uncertainty, 54 (2), p.103-28, 2017.

VUJIC, S.; COMMANDEUR, J.J.F.; KOOPMAN, S. J. Intervention time series analysis of crime rates: the case of sentence reform in Virginia, Economic Modelling, v. 57, issue C, p. 311-323, 2016.

\section{Cristiano Aguiar de Oliveira}

https://orcid.org/0000-0003-4933-6616

Doctor in Applied Economics at the Federal University of Rio Grande do Sul (UFRGS). Assistant professor at Federal University of Rio Grande (FURG), Brazil. 
E-mail: cristiano.oliveira@furg.br

\section{Appendix}

Figure A.1. Correlogram and residuals distribution from the estimated model
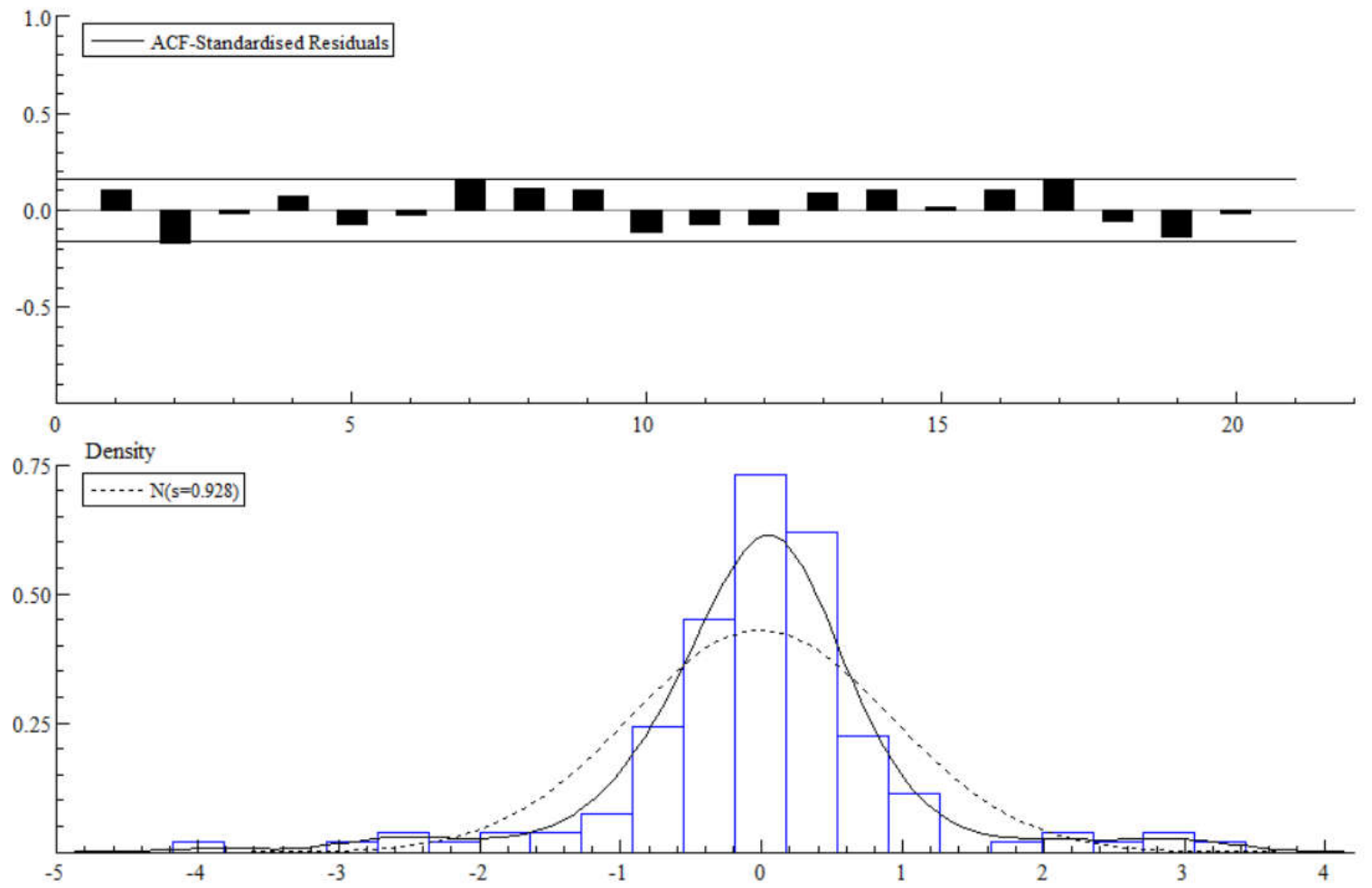